\title{
Women as Agents in Fertility Decision-making: Australia, 1870-1910
}

\author{
Peter MCDonald \\ Helen MOYLE
}

CONVEntional THEORIES OF fertility transition such as demographic transition theory and demand theory give little, if any, attention to the role of women as agents in fertility decision-making. These theories are based primarily on macro analysis in which correlations are drawn between particular macro trends and aggregate fertility rates. In the historical study of fertility transition in the West, many such trends have been invoked including urbanization, industrialization, changes in wage rates and economic wellbeing (e.g., the growth of the middle class), occupational change, changing opportunity structures through expanded social mobility, increases in education of fathers and/or mothers, compulsory education of children, changes in family structure (extended to nuclear), and secularization (Alter 1992; Banks 1954; Becker 1981; Caldwell 1976, 1999; Easterlin 1975; Lesthaeghe and Wilson 1986; Notestein 1945; van de Kaa 1996).

At the commencement of the Western fertility transition, most if not all societies were patriarchal in orientation, with men controlling the important social institutions associated with having children including government, religion, the law, industry, and the family. By inference, the Western fertility transition has been seen as being necessarily a result of men wishing to exercise control over fertility for mainly economic reasons and women being the passive beneficiaries rather than active agents of change. Major studies of contraceptive methods used during the West's historical fertility decline have dismissed evidence that women used female-controlled methods to limit their fertility (McLaren 1990; Szreter 1996; Szreter et al. 2003). Where reference was made to the means of fertility control, male-controlled methods, especially withdrawal and abstinence, better fitted a male-led theoretical perspective, and evidence has been advanced to support this conclusion. The argument was made that contraceptive appliances, including standard female methods like pessaries, syringes, and sponges, were too expensive for widespread use, their supply was low, and there was hostility to their use (McLaren 1990; Szreter 1996). 
The inference then made was that an inexpensive male method, withdrawal, must have been the main method and this was a method in the control of men (McLaren 1990). Szreter (1996), however, considers that abstinence was the main method of birth control during the fertility transition in Britain, arguing that this was also a male method of birth control. "Husbands were in fact practising sexual continence and radically reducing the frequency of sexual advances within the marriage" since "males were usually expected to take the sexual initiative in most marriages at this time" (Szreter 1996: 410). He argues, perhaps surprising, that a substantial proportion of wives were unaware that their husbands were controlling their fertility in this way. Szreter also concludes that in British society withdrawal was a type of sexual abstinence, since he considers that both methods are about "sexual self-restraint" (Szreter 1996: 420-1).

In this article, we use historical records to argue that, at least in the case of Australia but probably also many other Western societies, women were not only active agents but possibly the principal agents in fertility decisionmaking from the late nineteenth century onward. We are, of course, not the first to argue that the role of women has been understated in the literature on the fertility transition. For example, this argument was made strongly by Folbre (1983), who wrote that the failure of the then conventional theories of the historical fertility transition to incorporate the agency of women was "a fatal error of omission" (Folbre 1983: 267). The idea of women being agents in fertility decision-making is also implicit in contemporary gender equity theory (McDonald 2000). For Australia, the argument that women were central agents in the historical fertility transition has been made by Cook (2000), Anderson and Mackinnon (2015), and Moyle (2015). We build on these and other earlier works by placing the argument within Giddens's (1984) theory of structuration.

Australia provides an interesting case study because the evidence for the role of women as agents of change using female methods of contraception as well as abortion is more overt in the historical literature than it is in most other Western transitions. In particular, a government inquiry conducted in 1903 provides first-hand evidence of fertility control practices in Australia. While Australia may have been a special case, we also present limited evidence from other countries that supports the use of female methods of contraception during the historical fertility transition.

\section{Fertility transition and Giddens's theory of structuration}

Observed trends in the fertility rate of a society are the accumulation of the agencies of individual men and women in having or preventing births, but quantitative measures of agency (individual motivations and the capacity to act upon them) are rarely available, particularly in the historical context. 
In large part, this lack of evidence is the reason that individual agency has tended to be ignored. Diffusion theory, which addresses the ways in which ideas about fertility control were transferred across a society, incorporates individual actors. However, while diffusion of ideas is a necessary part of the explanation of the historical fertility transition, diffusion can only be effective when the recipients of information are motivated by the circumstances in which they live and are able to act upon those motivations. Information, motivation, and the capacity to act are the three conditions for fertility decline specified by Coale (1973). These conditions incorporate interaction between the micro (individual) and the macro (societal) levels. Giddens's theory of structuration provides a useful theoretical approach for the consideration of this interaction. Giddens also emphasizes the significance of historical time and place and the life histories/experiences of individual actors. This justifies the use of historical method and the focus on place that we take here.

According to Giddens, "Agency concerns events of which an individual is a perpetrator, in the sense that the individual could, at any phase in a given sequence of conduct, have acted differently. Whatever happened would not have happened if that individual had not intervened" (Giddens 1984: 9). He says that agency can be intended or unintended, as can the consequences. The use of a contraceptive device is clearly an intended action and therefore, except in rare circumstances, has motivation. The immediate intention of an individual woman in using a contraceptive device is to avoid pregnancy. If the method is used effectively, the intention is realized. If the method fails and she becomes pregnant, then this is an unintended consequence-but an unintended consequence that is no different from what would have occurred if she had not exercised agency. However, if the society's birth rate falls, this is evidence that methods have been adopted and intentions realized simultaneously by large numbers of individuals. At the same time, it was not the intention of the individual actors to reduce the society's birth rate; this was an unintended consequence of the simultaneous individual actions of many agents. This unintended consequence illustrates the interaction of the micro and the macro levels. An important component of Giddens's theory is that agency implies power or having sufficient autonomy to act in the way that the agent acts. Theory then must address the source of this power or autonomy. This is the essence of structuration theory.

The essence of a patriarchal society is that power lies with men, and women are the passive recipients of the consequences of men's decisions. Thus, implicit in our argument that women were central agents of fertility decision-making is the proposition that the patriarchal system had been modified to such an extent that women had this power or autonomy. Four concepts are important in Giddens's theory: structure, system, institutions, and the duality of structure. Structure refers to the patterning of social 
relations or social phenomena. Structure (patriarchal society in our argument) is a set of rules and resources that defines the system (the gender system) that shapes the nature of social institutions (marriage and the family, the labor market, education, etc.). Structure is reinforced when agents act according to the rules (all important decisions are made by men). This reinforcement is the duality of structure: in Giddens's terms, people make society but at the same time are constrained by it.

When social change occurs, its explanation must be sought at both the macro level (institutions) and the micro level (agents) and in the interaction between the two. If women become central agents of fertility decisionmaking in a system of institutions until recently characterized by patriarchy, social change has occurred. We must then trace this change through changes in the behavior of individuals and changes in the nature of social institutions as well as the interaction between the two levels.

At the political level, forces of conservatism will strive to preserve and protect existing structure and the long-standing nature of institutions. Social change occurs when conservatives lose the battle. Individuals acting alone are unlikely to produce this result; some form of group political agency is implied, however covert or diffuse it may be. We argue here that there are historical periods when conservatives lose many battles simultaneously and social change is rampant across a wide range of structures and institutions. In the context of women's agency, first-wave feminism (1880s) sits within such a period.

Using this theoretical approach, we examine women as agents in fertility decision-making in Australia during the period of the initial fertility decline between 1870 and 1910 when fertility fell from an average of over six children per woman to under four.

\section{The Australian fertility transition, 1870-1910}

Australia began its history of European settlement as a group of colonies established for the rehabilitation of convicted felons from Britain who worked primarily for a small number of pastoralists who took up (squatted upon) land in the various colonies. Through the 60 or more years that transportation of convicts occurred, six men arrived for every woman. By the late 1830s, the number of convicts was inadequate for the labor demand, and government-sponsored schemes were set up to bring agricultural laborers and tradesmen to Australia in family groups. In addition, from the 1830s to the 1850s, boat loads of single women were brought from Britain, primarily from Ireland, to serve as domestic servants but overtly or covertly to balance the sexes in the colonies (McDonald 1974). With the exception of the majority of pastoralists, the settlers came from poor backgrounds and Australia offered them opportunities for advancement. The exception to this history was the colony of South Australia to which no convicts were 
sent and which was established from its beginnings in the 1830s through settlement of family groups.

In the years to 1850, the large numbers of single male pastoral workers including convicts provided Australia with the image of a society that was heavily male-oriented, the stuff of Ward's The Australian Legend (Ward 1966). In the latter part of the nineteenth century, this image of Australia obtained further credence through the works of impressionist artists such as Tom Roberts, Frederick McCubbin, and Arthur Streeton and writers such as Henry Lawson and A. B. Paterson, all of whom were themselves living bohemian life styles in Melbourne or Sydney. In the 1880s Lawson's mother, Louisa Lawson, was an early campaigner for women's suffrage and advocated for divorce equality for women and for a labor union of married women. She employed female printers in her publishing firm and successfully resisted a campaign by male unionists to force her to dismiss her female printers. Criticized by the male editor of the magazine The Bulletin's Red Page, she responded "and why shouldn't a woman be tall and strong" (Radi 1986). We argue that the male-oriented image of colonial Australia, while true in some respects, concealed an underlying reality of strong and determined women. Louisa Lawson was truly exceptional but she was no exception.

No event changed the course of history in Australia more than the discovery of gold in the colony of Victoria in the early 1850s. People rushed into Victoria from all over the world including from the gold fields of California. The previous convict heritage was swamped. The population of Victoria increased from 77,000 in 1851 to 539,000 in 1861. Melbourne was transformed from a small town in 1851 to a thriving metropolis by 1861 and, by 1881 , built on wealth from gold, one of the grandest and wealthiest cities in the world (Briggs 1968; Davison 1978). Many of the new arrivals were educated and cosmopolitan. This transformation corresponded to the granting from the 1850s of self-government to the various Australian colonies by the British Government.

Between 1856 and 1880, 1.47 million births were registered in Australia (McDonald et al. 1987). Allowing for about 6 percent underregistration of births (Kippen 2002) and applying a survival ratio of 0.79 (West Level 15), we would expect around 1.23 million Australian-born children to have been aged 0-24 years at the 1881 round of colonial censuses. The total population of persons aged $0-24$ years at the 1881 census was 1.34 million. From these estimates, it is safe to conclude that over 90 percent of persons aged 0-24 in Australia in 1881 were Australian-born. This was the first large-scale, Australian-born generation. With the advent of compulsory education from around 1870 in the Australian colonies, almost all children, including girls, went to school. Victoria's Education Act 1872 mandated attendance at school for children between ages 6 and 15. By 1881 in Victoria, 98 percent of 20-24-year-olds could read and write, 50 percent of all 
children at school were girls, and 58 percent of all teachers were women (Victoria 1881). Many of the women who later led the movement for female suffrage in Australia had begun their careers as school teachers. Thus, not only did girls have female role models in their teachers, but boys also saw that women could be competent professional members of the workforce and leaders in the community.

While elites who were aged 25 years and older in 1881, including both Australian-born and British-born persons, may have practiced family planning during the 1870s (Moyle 2015), these groups were relatively small and their behavior would have had only a small effect in the aggregate. The fertility transition in Australia, as shown in Figure 1, took off in earnest from the cohort born in 1857-61 and was sustained by subsequent birth cohorts. Prior to this cohort, among the cohorts of women who married at young ages during the years of sex imbalance (McDonald 1974), completed fertility was exceptionally high (Ruzicka and Caldwell 1977; Moyle 2015). The modal number of children fell from eight for the 1847-51 birth cohort to five for the 1857-61 cohort and to three for the 1872-76 cohort. Therefore, while others have emphasized the role of immigrants in Australia's historical fertility transition (Ruzicka and Caldwell 1977; Anderson and MacKinnon 2015), the transition in Australia was clearly the outcome of the behavior of this first large generation of universally educated, Australian-born women and men.

FIGURE 1 Percent of ever-married women having specified number of children ever born, by women's birth cohort, according to the 1921 Census of Australia

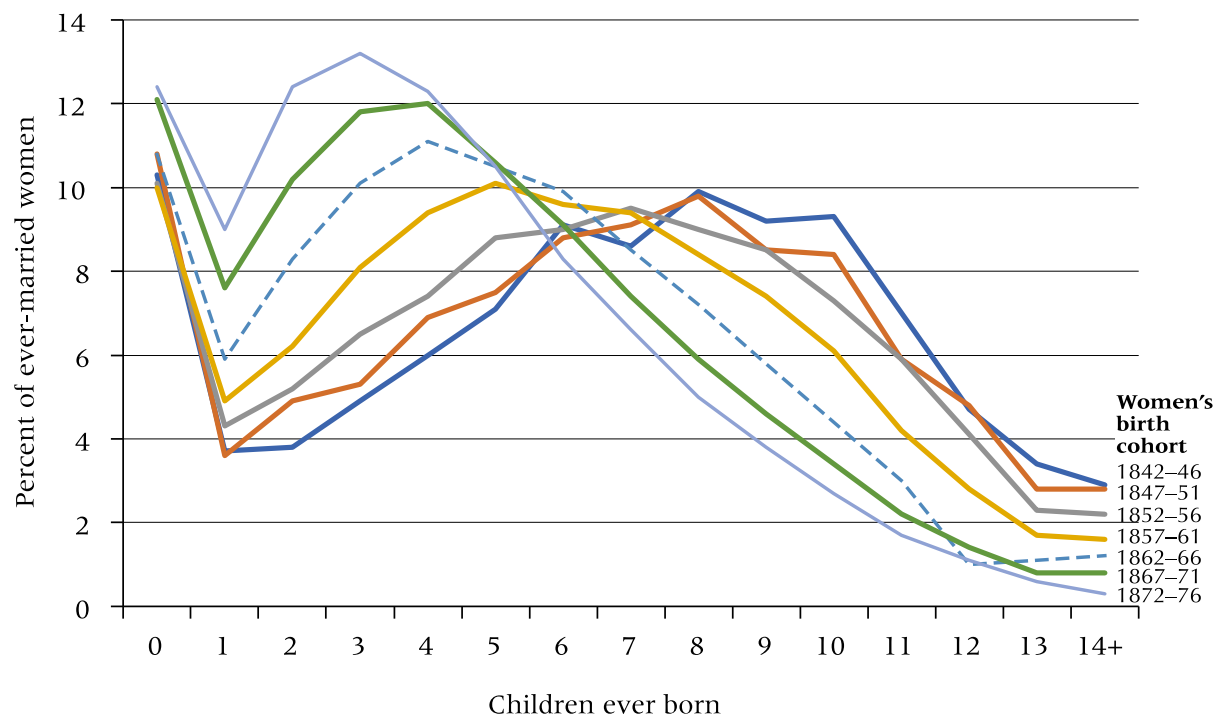

NOTE: Authors' calculations from data published in Commonwealth of Australia 1921, p. 1926. 


\section{Women and the nature of institutions in Australia}

The institutions of power in late-nineteenth-century Australiagovernments, government bureaucracies, churches, and the legal profession-were totally male dominated. Women did not have the right to vote nor did they hold positions of power in these organizations. From this perspective, colonial society was patriarchal. Men made and administered the rules, and other men and all women followed them. Ruling men tended to be British in their orientation, although the public viewpoint was that the colonies outshone the home country in economic and social progress (Coghlan 1887). In colonial legislation, conservatism prevailed because, ultimately, colonial legislation was subject to the conservatism of the British House of Lords.

A relevant example of this is law relating to divorce. In 1857, the British Parliament passed a divorce law and all Australian colonies were advised by the Colonial Office to pass a similar law, which they did. However, the English law did not treat wives and husbands equally: adultery and desertion on the part of the husband were not a sufficient reason for divorce; on the part of the wife, they were. From the beginning, there was a great deal of opposition to this inequality, including among leading legislators in Australia. All attempts over the next 40 years to widen the grounds of divorce and create equality for men and women were disallowed by the British Government on the grounds that it was improper for the colonies to run ahead of the home country in their legislation (Finlay 1999). While power prevailed to institutionalize a patriarchal system, the level of opposition expressed through the pages of colonial newspapers in editorials and letters from both men and women was indicative of a sentiment in the colonies that viewed women more highly than was the case in the home country. Reference was made to the destitution of women and children deserted by husbands and fathers. This was offensive to at least some of the colonial leaders because their aim was to create a society that was just, wealthy, and prosperous and not based on hereditary privilege.

Nevertheless, conservatism and patriarchy remained evident in many aspects of government. For example, at a mid-1880s meeting of colonial statisticians, they expressed their concern about the number of women who at censuses up to 1881 had been classified as engaged in farming, creating an impression that "women were in the habit of working in the field." They then issued instructions for the 1891 round of censuses that women in such circumstances should be classified as performing "domestic duties" (Victoria, Office of the Government Statist 1893: 192).

Ironically, the statisticians took this action around the same time as the first female trade union was created in Australia (The Tailoresses Association of Melbourne formed in 1882), which called a strike in February 1883. 
The strike was supported by the major Melbourne daily newspaper, The Age, and was even supported by the company from which the workers had struck so long as other tailoring companies agreed to the same conditions (O'Lincoln 2005). The Victorian Lady Teachers' Association, established in 1885, was Australia's first permanent teachers' union (Spaull 1984: 166). The three Weekes sisters who were leaders of this association campaigned for women's suffrage, equal pay, and equal promotion opportunities for men and women. This direct action by women in the labor force is evidence of considerable agency on the part of women in shaping their lives.

The six Australian colonies federated to become the independent nation of Australia in 1901. Full female suffrage was introduced the following year. Australia thus became the first sovereign nation in the world to grant the vote to women, long before the United States, Canada, and the United Kingdom. ${ }^{1}$ The struggle for female suffrage in Australia was nowhere near as difficult as it was in these other English-speaking countries. This supports an argument that acceptance of women's agency was more advanced in Australia than it was in these other countries.

There is debate about how important working women were in Australia's early adoption of full women's suffrage (O'Lincoln 2005) as opposed to middle- and upper-class women who argued that female suffrage would be a civilizing force. For example, the leading Melbourne feminist, Vida Goldstein, who had been educated at a private girls school in Melbourne, argued for female suffrage on the basis that "the stability of marriage and the home depend upon having an equal standard for men and women" (cited in Serle 1988: 22). In 1891, Goldstein at the age of 21 assisted her feminist mother in the collection of 30,000 signatures in support of female suffrage in just six weeks, the largest petition that had ever been presented to the Victorian Parliament. In a much later interview, she said of the petition: "Very rarely were refusals made by wives of working men and by women who took part in social reform work outside the home" (Argus, 28 October 1937, cited in Wright 2014).

The Australian suffrage movement was not especially formalized; the main organizational support came from the conservative Women's Christian Temperance Union. The involvement of people and organizations that were both progressive and conservative and the activism of women from both sides probably explain why female suffrage was obtained so early and so easily in Australia. In contrast, full female suffrage was achieved in the United Kingdom 26 years later than in Australia and involved marches, civil disobedience, police harassment and surveillance, arrests, hunger strikes, and a death. The achievement of female suffrage in the United Kingdom has been portrayed as a battle of men against women (Kent 2014). The fact that it was not like this in Australia suggests that women's agency was given more credence by the established institutions despite their inherent patriarchal nature. Our interpretation is that the first large generation of 
Australians, both men and women, was educated, relatively secular in orientation, open to the opportunities for social mobility, and not constrained by the rigid patriarchal structures with which suffragists in the United Kingdom had to contend.

This was also a time when many new occupations emerged that provided opportunities for the new, educated Australian-born generation. There was rapid growth in white-collar occupations such as accountants, bank clerks, insurance clerks, school teachers, and railway porters (Moyle 2015). The proportion of jobs that were rural declined. Mining beyond gold mining also took off in this period, with the mines being run by major companies. The miners were men who had worked at other jobs in other places, and the younger ones were educated. They were quite unlike miners in British towns who had been miners all their lives and had always lived in the same place. Moyle (2015) found that, in Tasmania where mining was prominent, there was no significant difference in the fertility rates of miners' wives and the wives of white-collar workers or skilled tradesmen. Between 1861 and 1901, 77 percent of population growth in the colonies of New South Wales, Victoria, and Queensland was in urban areas (Burnley 1980: Table 3.4). In the 1880s, suburbanization took off in the major cities, supported by new transport networks of rail and tram lines. In the suburbs, a construction boom led to the building of workers' cottages, and finance was available that put purchase of these houses within the reach of the more successful workers (Davison 1978). The middle-class, suburban lifestyle was open to a wide range of families and many aspired to achieve it. Early marriage and a large number of children were obstacles to its achievement (McDonald 1974).

The high aspirations that developed in the 1880s were shattered by the financial crash of 1890 that gave rise to a severe, long-running economic depression. By the time the economy recovered, the country was hit from 1902 by a drought that had major effects upon commodity exports. Thus, while high economic aspirations were generated and often achieved during the 1880s among the first large Australian-born generation, the capacity to achieve these outcomes was much reduced in the period from 1890 to 1910. A large gulf between high economic aspirations and the reality of poor outcomes is theorized as being a major stimulus to the control of fertility (Casterline 2001; Abbasi-Shavazi et al. 2009) and this was almost certainly the case in Australia in this period.

Moyle (2015) describes many other changes in the daily lives of people that are relevant to our argument. From the 1870s, the telegraph enabled the publication in the Australian press of reports in British newspapers within days of their original publication. Pertinent here are reports of the trial of Bradlaugh and Besant in London for publishing a book about methods of birth control-Charles Knowlton's Fruits of Philosophy. Advances in transport, trains, trams, and even bicycles made it easier for people to travel, 
and nineteenth-century diaries indicate that upper-class women moved freely around the colonies and traveled farther afield to the large cities and even to Britain unaccompanied by husbands. Working-class women also were reported to have been in contact with their relatives living in distant places and to have traveled to see them. Moyle (2015) refers to the extensive social and cultural life of the upper class in Australian cities and to the secular nature of Australian society at the time.

The rise of secularism assisted women to free themselves from the moral codes of patriarchy enshrined in the Christian denominations. Historians generally agree that in the early decades of the colony, the majority of the Australian population did not have a strong religious affiliation (Boyce 2010; Breward 1988, 1993; Reynolds 2012; Robson and Roe 1997). Religion was generally not as important to people in Australia as in Britain or the United States (Breward 1988). By the 1850s and 1860s, religious groups in Australia did not have a strong influence on people's political and social attitudes and values. The Anglican Church, like other denominations, reflected "the political and social realities of its community rather than shaping the community" (Breward 1993: 45).

At all social levels, women were the household managers and, as such, they were acutely aware of the additional costs that an extra child entailed. They were also acutely aware of the risks of death associated with frequent childbearing and the risks of becoming a widow.

Thus, while there has been an impression (supported by early historical writing) that Australian women in the late nineteenth century were living in a male-dominated colonial (even, primitive) environment, the reality seems to have been far different. We argue that the first large generation of Australian-born women was dominated by educated women who were active participants in their own destinies. They mainly lived in cities, they participated in social and community occasions, and, among the upper classes, led lives as sophisticated as those of equivalent women in other world cities. In some respects-for example, female labor unions and female suffrage-they ran ahead of their counterparts in other Western countries. This is not to argue that their exercise of agency was unique; rather that it was clearly significant.

\section{The means of fertility control, 1880-1910}

The previous discussion described the macro-level institutional changes that took place in Australia during the historical fertility transition. It also documented the importance of women's agency in institutional changes. We now show how women were central agents in the use of fertility control methods during this period.

Much of the information in support of women's agency in the use of contraception comes from witness statements and other published 
material from the 1903 New South Wales Royal Commission into the Decline in the Birth Rate (NSW 1904a, 1904b), especially from the verbatim evidence provided by a wide variety of witnesses that was published in the second volume of the report. ${ }^{2}$ The Royal Commission was set up in 1903 to "make a diligent and full Inquiry into the Causes which have contributed to the Decline in the Birth-rate of NSW and the Effects of the Restriction of Child-bearing upon the well-being of the community" (NSW 1904a: 1). While the Commission took place in New South Wales, the Commissioners were confident that their evidence applied to the other colonies as well, stating in their report that "what applies to NSW is obviously no less applicable to the whole of Australasia" (NSW 1904a: 172). As a new nation (with Federation having taken place two years before), prominent Australians were concerned to promote population growth, which had fallen to low levels during the 1890s and early 1900s. The declining fertility rate was seen as being counter to these nation-building aims.

The creation of the Commission was evidence of a resistance to the changes that were occurring in women's lives (NSW 1904a, 1904b). For women, there was nothing more fundamental than having control over their fertility. The Commission was overwhelmingly male. All 13 Commissioners were well-established professional men and, of the 96 witnesses who were not Commissioners, only nine were women. Feminists boycotted the Commission. A noted feminist, Rose Scott, refused her invitation to appear before the Commission and gave speeches to women's organizations attacking the Commissioners for conducting this type of inquiry into women's affairs (Allen 1990).

Meetings of the Commission were held in Sydney to take evidence from witnesses face to face, except for Statisticians from other Australian states, where questions were sent and answers received by mail (NSW 1904a: 10). Witnesses included officers of the Registrar-General's Department of New South Wales, customs officers, wholesale chemists and their salesmen, pharmacists and pharmacy assistants, medical practitioners (both specialists and general practitioners), superintendents or matrons of maternity homes or children's homes, officers of the State Children's Relief Department and the Children's Protection Department, police officers and policemen, representatives of labor organizations who were themselves skilled workmen, inspectors of factories and shops, ministers of religion, and other interested individuals. Most of the witnesses came from Sydney, but several lived in the country areas. Some witnesses were invited to present evidence, while others volunteered.

The Commissioners condemned women for using contraception and abortion to limit the number of births, but many of the witnesses, particularly the working men, expressed sympathy with the desire to have smaller families. 
In drawing their conclusions, the Royal Commissioners had no doubt about the agency of women in the fertility decline that they had investigated. They and many of the conservative male witnesses before the Commission concluded that the fall in fertility was due to the actions of women and to the spread of knowledge about contraception from one woman to another. For the Commissioners, women were the perpetrators of the "evil" that had led to the decline in the birth rate in this new nation that desperately needed additional people. There has been a tendency in Australian historical writing to belittle this conclusion by reference to the Commissioners' blaming the selfishness of women for the decline (NSW 1904a: 17). We argue that, while the Commissioners reflect contemporary patriarchal sentiments in the language they use in the report, they were perfectly accurate in attributing the decline to the agency of women.

Many witnesses before the NSW 1903 Royal Commission testified that the purchase and use of artificial methods of contraception had greatly increased in the preceding 20 years, as had the practice of withdrawal and abortion. Other evidence shows that in the late nineteenth and early twentieth centuries, wholesale drug companies imported French letters (condoms), the India-rubber Pessaire Preventif, Rendell's soluble pessaries, and safety sponges into NSW (NSW 1904b: 13,15). Some wholesale druggists and pharmacists also made their own soluble pessaries (NSW 1904b: 15, 20). Enemas, douches, and syringes sold by pharmacists were also used for contraception.

Witnesses before the Royal Commission agreed that almost all pharmacists in Sydney stocked contraceptive devices, but this was not the case in the rural areas. Some Sydney drug companies and pharmacists sold preventives to people in rural areas by mail (NSW 1904b: 21, 44). Preventives were also sold by hawkers, including women, in both the city and the country (NSW 1904b: 18, 24, 27).

Indicative of the demand for female preventives, in the late $1890 \mathrm{~s}$ Washington Soul, the largest pharmacy in Sydney, established a "nurse" in a kiosk in its city store solely for the purpose of selling articles to women. Nurse B. told the Commissioners: "My particular duties are to attend to ladies with articles that are kept in my room .... I have sold women rubber pessaries or medicated pessaries and safety sponges" (NSW 1904b: 57). However, most manufactured contraceptives were relatively expensive in relation to the average wages of working-class and even some middle-class men, and this fact has been used to argue that these forms of contraception could not have had much impact on overall fertility (McLaren 1990; Szreter 1996). The Royal Commission also points out that manufactured contraceptives were expensive relative to wages. The wages of working men ranged from around 30s to $£ 2$ 8s per week while lower white-collar workers generally earned from around $£ 2$ to $£ 3$ a week (NSW 1904b: 29, 45, 106, 2645). India-rubber pessaries cost from $8 \mathrm{~s} 6 \mathrm{~d}$ to $£ 22 \mathrm{~s}$ each, soluble pessaries 
from 3s a dozen, and French letters from 6s a dozen (NSW 1904b: 363$5,383,385)$. Despite this, the Royal Commission report provides a picture of a thriving contraceptive industry in New South Wales, and this would not have been the case if contraceptives were too costly for the majority. Many possibly saw the costs of an additional child as outweighing the cost of contraceptives. Even when shop-bought contraceptives were too expensive for some women, their purchase and use, through the process of diffusion described by the Commissioners, would have provided a stimulus for use of contraceptives by poorer women. Many witnesses told the Royal Commission that it was common for women to use less expensive methods of prevention or to make their own preventives, and we argue that it was these "do-it-yourself" methods that had the main impact on overall fertility especially after 1890 .

Several witnesses testified that the use of syringes, douches, and enemas was common. William Sharland, representative of the Parke Davis Drug Company, said "I think that the latter are the growing class of preventivesthat is the douching of the canal with enemas and douches with antiseptic solutions (NSW 1904b: 24). J. A. Masterton, a pharmacist in Market Street, Sydney, said "Others will not go to the expense of anything; they simply use their syringe with an astringent lotion straight away, and that answers the purpose just the same" (NSW 1904b: 30). Dr. Robert Scot-Skirving, a physician and surgeon at two major Sydney hospitals, reported that "In the bush, and among the lower classes generally, the preventive as a rule, is syringing immediately after connection either with hot or cold water" (NSW 1904b: 101).

Many witnesses told the Commissioners that women made their own soluble pessaries. Masterton said "Referring to these soluble pessaries, they are made of cocoa butter, which is the vehicle to carry the quinine that is in them, and is the sterilising agent. Now a great number of people buy cocoa butter by itself, and they buy quinine by itself" (NSW 1904b: 30). George Stevens, a pharmacist in a working-class inner-city area of Sydney, reported "They come and buy $3 \mathrm{~d}$ worth of cocoa butter and some quinine and they mix it up themselves" (NSW 1904b: 43). Dr. John Harris, who had been a general practitioner in Newcastle (NSW) for 30 years, said "There are a larger percentage of women now who know how to prepare their own pessaries. They use quinine and sulphate of zinc and make them up with cocoa butter themselves. It is common for women to make their own pessaries and introduce them into the vagina and leave them there" (NSW 1904b: 125).

Several witnesses testified that it was common for women to use sponges for preventive purposes, with many women making their own contraceptive sponges. Sir James Graham, an Honorary Surgeon to two major Sydney hospitals, said "One frequently finds, in the ordinary outdoor clinic ${ }^{3}$ of a woman's hospital, evidence of sponges and the like" (NSW 1904b: 
114). Masterton reported that "There are sponges used-small sponges. Now these sponges are designed for the same thing. Well, a great number of people will not go the trouble of buying a sponge. They buy the ordinary toilet sponge and cut it into pieces and they tie a tape to them, and they use them themselves" (NSW 1904b: 30).

Several doctors gave evidence to the Royal Commission that withdrawal was used to prevent conception. Dr. Scot-Skirving said "I think that withdrawal is practised to a considerable extent" (NSW 1904b: 101). Dr. William McKay, Medical Officer at a suburban Sydney hospital, told the Commissioners that "The main method is the withdrawal of the male organ before the act is completed" (NSW 1904b: 105). Dr. Worrall, Senior Visiting Surgeon to the Sydney Women's Hospital, also thought that withdrawal was very common (NSW 1904b: 88).

Some scholars have used this testimony about withdrawal to conclude that it was the most common method used to prevent conception during Australia's historical fertility decline (Bongiorno 2012; Pringle 1973; Quiggin 1988), but evidence from other witnesses before the NSW Royal Commission, as outlined above, does not support this view. Additionally, when McKay's statement is examined in more detail, it appears that he is primarily talking about the use of withdrawal by the middle classes. "Prevention is more common in the middle classes. I mean men earning say $£ 2$ a week in offices .... it is not so common among the working classes, because the man will not submit to it. The woman might be quite willing, but the man will not submit" (NSW 1904b: 105).

While withdrawal is part of the picture, overall, witnesses before the Royal Commission indicated that female-controlled preventives, that is, soluble pessaries, syringes, douches, enemas, and sponges, were commonly used by women of all classes to prevent pregnancy. Soluble pessaries were more popular than condoms, which were used to prevent disease as well as conception (NSW 1904b: 16, 29). Most pharmacists reported that the sale of pessaries had overtaken that of condoms in recent years. George Stevens said "There is not much sale for the French letters since the pessaries have come into vogue" (NSW 1904b: 43).

Abortion, too, was used to limit family size in Australia in the late nineteenth and early twentieth centuries, despite being a criminal offense. Until Federation in 1901, the Australian colonies were subject to the UK Offences Against the Person Act of 1861, which made abortion illegal under any circumstances. After Federation, abortion remained a criminal offence under different State legislations.

Most witnesses before the NSW Royal Commission attributed the decline in the birth rate to both prevention and abortion, with many saying that prevention was more commonly used by the middle class to limit family size and abortion more commonly used by the working class (NSW 1904b). Almost all witnesses-doctors, pharmacists, clergymen, police officers, and 
others-reported that induced abortion was a common practice among both married and unmarried women. Most pharmacists reported a demand for pills used by women to try to induce abortion, such as Towle's Pennyroyal and Steel Pills and Dr Boxwell's Silent Pills (NSW 1904b: 357). Abortifacient pills were sold throughout Sydney and in all rural areas (NSW 1904b: 28). They were also available by mail through advertisements in newspapers (NSW 1904b: 30; see the following section).

Witnesses before the Commission reported that many abortionists were operating in Sydney and some in country areas. These were mainly nurses (qualified or unqualified) and a very small number of doctors in Sydney, and unqualified midwives in the country areas. James Sawtell, Senior Sergeant of Police in Sydney, thought that the procuring of abortions was very prevalent in Sydney: "I know of 36-38 reputed abortionists, mostly women, in my own district. I also know of five legally qualified medical men" (NSW 1904b: 52). Dr. Joseph Foreman, Senior Gynecological Surgeon to the Prince Alfred Hospital, said "The prevalence of abortion is almost incredible. The cases that are always coming in and taking up the beds in the hospitals are quite sufficient to show to what extent it prevails" (NSW 1904b: 229). Most of the witnesses agreed that women of all classes used abortion to limit their families, but thought that the practice was more common among the working class. Dr. Arthur Glover, a general practitioner in a poor working-class district of Sydney, told the Commissioners of the desperation of some of his married women patients: "They are aware that abortion is a criminal act .... and several of them, if you tell them how dangerous it is, say they will die before they will have another child" (NSW 1904b: 110). Many witnesses reported that it was common for country women to come to Sydney to procure an abortion.

McCalman's (1988) study of female patients at a large public hospital in Melbourne shows that abortion was common in the late nineteenth century. In Adelaide, a number of cases of abortion by a well-known abortionist, Madame Harper, were reported in the local newspapers in the late nineteenth and early twentieth centuries (Anderson and McKinnon 2015).

None of the evidence provided to the Commission mentioned the use of abstinence as a preventive measure. Clergymen giving evidence spoke of their strong opposition to the common practice of using artificial methods to prevent conception and to abortion, but did not discuss or recommend the use of abstinence to control family size.

We are not arguing that the home-made methods that were used, primitive by today's standards, were as effective as modern methods of birth control. The high incidence of abortion among married women can be taken, in part, as evidence of contraceptive failure. More directly, in the absence of evidence of widespread use of abstinence, the emergence of very long final birth intervals provides powerful evidence of "failed stopping" behavior in which women, or couples, attempted to terminate their lifetime 
childbearing through contraception but failed to do so. For example, Moyle observed the emergence of very long final birth intervals (more than six years) in Tasmania in the 1890s and early 1900s for women whose completed fertility was four or five births (Moyle 2015: Table 7.10). Most of these women were still comparatively young (aged less than 35 at the penultimate birth), so declining fecundity was not the explanation. Furthermore, there was no change for these women in the length of the final birth interval compared with similar women in earlier years. Thus, it is evident that fertility control was being practiced to terminate childbearing at relatively young ages and, when it failed, it still often provided protection for long periods, and the Tasmanian evidence is that couples rarely failed more than once. In simple terms, imperfect contraception has a larger impact than no contraception and, apparently, an impact sufficiently large to influence total fertility especially when it is backed by abortion. If these methods had not been relatively reliable, women would not have continued to use them over such a long period of time.

\section{Diffusion of knowledge about fertility control}

There is considerable evidence to support diffusion of knowledge as integral to the explanation of the historical fertility decline in Australia. Ideas and values about fertility control, as well as the knowledge of the methods used to limit fertility, clearly spread rapidly through Australian society in the late nineteenth and early twentieth centuries.

The 1903 NSW Royal Commissioners considered that the spread of values regarding fertility limitation and information about fertility control methods was one of the main reasons for the fall in the birth rate from the mid-1880s (NSW 1904a). They reported that, in the last quarter of the nineteenth century, values about fertility control had spread throughout the "civilised world" and there was a "general diffusion of the knowledge of methods by which restriction might be accomplished which was previously wanting" (NSW 1904a: 17).

Birth control literature from overseas became available in Australia from about the 1880s onward. Books and pamphlets about birth control such as Fruits of Philosophy by Charles Knowlton and The Law of Population by Annie Besant, were available in Sydney and Melbourne bookshops, and lectures on family limitation were given in Melbourne and Sydney (Bongiorno 2012; Quiggin 1988; NSW 1904b). Many witnesses before the Royal Commission mentioned Fruits of Philosophy, and several of them had read it. The Commission also heard evidence that pamphlets advertising preventives were in circulation in Sydney. James Mitchell, Sub-Inspector of the Police, said of a handbill advertising the French Pessaire Preventif, "Many complaints have been received from citizens that handbills of this character have been left at their houses with their female relatives. 
They are left door to door and we have had complaints of their being sent to people by post or other means" (NSW 1903b: 51). It is not clear whether these books and pamphlets were available to the same extent in rural areas as in the city. The Reverend John Howell Price, a Church of England clergyman from Richmond, a then-rural area just outside Sydney, said that "Bradlaugh's books and Mrs Besant's books and other books which are freely obtainable in Sydney are largely read in country places" but thought that leaflets and pamphlets were not generally distributed in country areas (NSW 1904b: 214). Henry Allbutt's The Wife's Handbook, circulated in Britain by Allbutt himself at very low cost, was published in Australia by the Modern Medical Publishing Company and distributed widely from Sydney by the mail-order bookseller Sir Robert Bear, including outside of Australia.

From the late 1880s, Brettena Smyth, a widow and publicly avowed secularist who ran her own pharmacy, gave frequent, women-only lectures in the North Melbourne Town Hall and in other locations around Victoria, including the country town of Bendigo, that were attended by hundreds of women at a time (Kelly 1982, 1990). She had a commanding presence at six feet tall, was Australian-born and educated, and was an early suffragist and a promoter of a broad range of social causes. Her lectures covered aspects of reproductive health including the use of contraceptive devices. The lectures were freely advertised and reported upon in the leading Melbourne newspapers. Also of interest, her lectures usually began at 8:00 pm, indicating that women were free to move around the city at night to attend such events. A newspaper report in The Record (Emerald Hill) stated of one of her lectures in the North Melbourne Town Hall the previous Monday night: "There was a large attendance, notwithstanding the misfortune of a very wet night, proving the growing popularity of our Australian lecturess. The subject was on limitation of offspring which was capably and intellectually handled showing that the matter has been consistently considered by the lecturess ... The matter was made clear and intelligible by pictorial illustrations and diagrams" (The Record (Emerald Hill), 30 September 1893, accessed through Trove, National Library of Australia).

The matter-of-fact way in which this report is made in a freely available newspaper and the very large attendances at Smyth's lectures argue against the notion that contraception was a taboo subject in Victorian times, especially in relation to women. Mrs. Smyth particularly promoted the Pessaire Preventif, which she described as the only female method that could be used without the knowledge of the husband. She also published her lectures as books and in pamphlets, such as Love, Courtship and Marriage (1892), The Limitation of Offspring (1893), The Social Evil (1894), and The Diseases of Women (1894). She sold all types of contraceptives in her shop, including the India-rubber French Pessaire Preventif, condoms, enemas and syringes, and sponges (Magarey 2001). She also sold books and 
pamphlets about sex education and birth control, including her own works. Kelly writes of Brettena Smyth: "As did many contemporary women activists, she saw a new kind of family and an enhanced role for motherhood at the heart of social reform. In her lectures and pamphlets, she argued that well-matched couples could form a more equal partnership. Planned families would mean fewer children, liberating women from the psychological and financial strains of unwilling pregnancy and motherhood" (Kelly 1990).

Advertisements in newspapers and journals were a major source of information about fertility control in late-nineteenth- and early-twentiethcentury Australia (Bongiorno 2012; Quiggin 1988). The 1903 Royal Commission found that the newspapers in metropolitan, suburban, and rural NSW regularly contained advertisements for books and pamphlets providing information about methods of prevention and for the sale of preventives and abortifacients (NSW 1904a: 30, 39, 50, 87, 95, 271-2). Dr. Edward Thring, gynecologist at a large Sydney hospital, thought that "The general public are familiarised very much more now than they used to be with the methods by which prevention of pregnancy can be made to take place ... and I think that one reason for that is the free advertising-I mean to say, the extensive advertising-the various preventive methods which has taken place during the last, say, 20 years-the knowledge that there are various mechanical means which can be obtained by purchase for the prevention of impregnation" (NSW 1904b: 93).

Police officers appearing before the Royal Commission reported that advertisements from well-known abortionists regularly appeared in the newspapers (NSW 1904a: 51-2,183). However, these advertisements were written in such a general way that it was difficult to detect their true purpose: "Nurse P. attends ladies during accouchement. Registered lying in home, 550 Cleveland St. Moore Park" (Sydney Morning Herald, 24 October 1902 cited in NSW 1904b: 186). Similar advertisements for "lyingin homes" appeared in the Tasmanian newspapers in the late nineteenth and early twentieth centuries, and it is likely that some of these establishments were also used to perform abortions (Moyle 2015).

In the last decades of the nineteenth century, a number of prominent people were tried for obscenity in England and Sydney because they were publishing and/or distributing information about methods of birth control (Bongiorno 2012; Caldwell 1999; Hacker and Kippen 2007). The Bradlaugh-Besant trial, which Caldwell argues was a catalyst for the adoption of birth control, was reported in all the Australian newspapers, including The Mercury and The Examiner. The Mercury reported on 13 August 1877: "The trial of Mr Bradlaugh and Mrs Besant, before the Lord Chief Justice and a special jury, lasted five days and in their verdict the jury found the defendants guilty of publishing a work calculated to debase public morals, but exonerated them from all corrupt motives. A new trial will 
be applied for, and Mr Bradlaugh intends to carry the case to the House of Lords."

Fruits of Philosophy was again referred to in an article in The Mercury on 25 August 1877 reporting proceedings in the British House of Commons, quoted verbatim from the London Times. Another article in The Mercury of 26 February 1878 compared an "obscene" pamphlet published in Melbourne to "that notorious work 'Fruits of Philosophy' published by Mr Bradlaugh and Mrs Besant, and for which they were deservedly convicted and sentenced to be fined and confined, though the conviction has since been upset in the Supreme Court."

Collins Booksellers in Sydney was tried for obscenity in 1888 for selling Annie Besant's book, The Law of Population, but, unlike courts in England in the Bradlaugh-Besant trials, Judge Windeyer ruled that the book was not obscene and that Collins had a right to sell it. This judgment was reported in newspapers in all the Australian colonies.

Many witnesses told the Commissioners that information about prevention was spread by word of mouth among women. Women discussed ideas and values about prevention with other women and gave them information on how to limit their births. The Reverend Howell Price said "One of the most intelligent ladies that we have in the district is a very keen advocate of prevention, alleging various reasons why prevention should be practised .... This information is communicated to the unmarried and to married persons" (NSW 1904b: 214). George Stephens, a pharmacist, reported "There is a peculiar thing about women; they will tell one another and they simply come along and ask for them ... [quinine pessaries] ...they spread the information amongst other women....Knowledge travels from one woman to another in the country" (NSW 1904b: 44). One of the few female witnesses, Witness E, a woman aged 47 who had borne 16 children, said "Ever since my early married life, some of my friends have spoken to me about prevention. They have advocated it....People seem to be well acquainted with the methods of preventing impregnation. I have been spoken to myself by different people about all sorts of ways. They discuss the different methods among themselves openly among women of every class" (NSW 1904b: 189). ${ }^{4}$ Dr. Joseph Foreman added "They acquire the knowledge from the propagandists amongst themselves ... there is one woman ... who goes about telling other women; at all the tea meetings, at all the drawing rooms, it is the subject of conversation. There is not a woman scarcely who comes to me who does not know what to do to prevent conception" (NSW 1904b: 228). The Rev. Nicholas Hennessy, a Congregationalist clergyman, thought that "Women themselves have helped to spread the evil .... they are very free [those of them who have either one child or very small families] to tell a woman who has many children the means by which she can prevent the birth of more" (NSW 1904b: 207). 


\section{Supporting evidence from other countries}

The argument in this article is greatly enhanced by the verbatim evidence provided to the 1903 NSW Royal Commission. As far as we are aware, such detailed evidence is not available for countries other than Australia for this period. In describing the macro-level and institutional changes that took place in Australia during the historical fertility transition and the importance of the agency of women in broader institutional changes, we have provided the context for the widespread use of contraceptive methods by Australian women. However, we hypothesize that it is unlikely that this Australian experience was unique and that there is at least limited evidence of similar forms of women's agency in the adoption of contraception in other societies in the late nineteenth and early twentieth centuries. Here we present the evidence that we have been able to unearth to this point. This evidence has proved to be remarkably consistent with that of Australia.

While authors have concluded that withdrawal and abstinence were the main methods used in England and Western Europe during the fertility transition, the evidence on which this conclusion is based is questionable (e.g. McLaren 1990; Szreter et al. 2003). For instance, Szreter et al. (2003) state that withdrawal was probably the main contraceptive technique used in French marriages in the early twentieth century. This conclusion, however, is based on "quantitatively thin" evidence that may be "biased"-namely, testimonies from 81 judicial cases, many of which concerned illicit sex including incest (Sohn 1996 cited in Accampo 2003: 258).

Evidence about the involvement of women in the fertility transition and the use of female methods of contraception has been dismissed as unimportant and irrelevant. A review of the evidence, however, shows that women played an important role in the fertility transition in other parts of the Western world in the late nineteenth and early twentieth centuries.

Pamphlets and books on birth control methods that were published and circulated in Britain, such as Francis Place's Diabolical Handbills, Robert Carlile's Every Woman's Book, Charles Knowlton's Fruits of Philosophy (the subject of the Bradlaugh-Besant trial), George Drysdale's Elements of Social Science, and Henry Allbutt's The Wife's Handbook, were directed to women and recommended female methods of contraception (Allbutt 1888; Branca 1975; Carlile 1828; Drysdale 1861; Knowlton 1834). Place and Carlile recommended the sponge and Knowlton the douche, while Drysdale recommended a combination of the two. Allbutt's illustrated book published later in the nineteenth century discussed several types of contraception, including the India-rubber Lambert's Check Pessary, "which can be used by the woman without inconvenience or knowledge of the husband" (Allbutt 1888: 49), and Rendell's Soluble Pessaries. 
Sponges and syringes were cheap and readily available to purchase. Pessaries had originally been prescribed by doctors for medical reasons, but in the mid-nineteenth century India-rubber pessaries became used as contraceptives. These pessaries were continually improved and by the early 1880s were advertised in British women's magazines and health manuals. India-rubber pessaries were expensive; however, in 1880, Walter Rendell, a London chemist, developed a pessary made of quinine and cocoa butter to meet the needs of the poor women in his district (Finch and Green 1963: 24). Rendell's pessaries were so successful that in 1886 he began to manufacture them on a large scale and was soon exporting them. In a refined form, they are still sold today in more than 30 countries.

By the end of the nineteenth century, an endless variety of contraceptive devices were available for women in Britain, which Branca considered indicative of a strong and continuing demand for these methods (Branca 1975). Female contraceptives and abortifacients were also advertised and sold widely in the United States in the nineteenth century, although the Comstock Act of 1873, which made the advertising of birth control devices illegal, had some impact on the circulation of information (Brodie 1994: 281). A 1914 study of working-class birth control practices in the north of England found that a wide range of marketing techniques were used to sell birth control devices and abortifacients (Elderton 1914). Advertisements, some of which were directed to women, were placed in newspapers; literature was available in chemists' shops; small handbills were posted in various locations; and pamphlets about birth control were sent to parents who had announced a birth in the newspapers.

McLaren (1990) agrees that in Britain in the latter decades of the nineteenth century, artificial contraceptive appliances, including female methods, and pills to induce abortion were advertised extensively in newspapers and magazines, sold in various types of establishments, including pharmacies, and peddled door to door in villages and working-class neighborhoods. However, he argues that there is little evidence that these methods were used widely. This conclusion does not seem logical since, as Brodie points out, it is unlikely that there would have been such a supply of information on female contraceptive methods and contraceptive products for sale if there were only limited demand for them (Brodie 1994).

Women in England and Western Europe also made their own contraceptives according to several reports. Carlile wrote of the sponge: "The practice is common with the females of the more refined parts of the continent of Europe and with those of the Aristocracy" (Carlile 1828: 39). On a visit to France in 1913, Margaret Sanger found that French women had learned to make their own pessaries from their mothers who had learned this from their mothers. "Some of the contraceptive formulas which had been handed down were almost as good as those of today. Although they had to make simple things, mothers prided themselves on their special recipes 
for suppositories as much as on those for pot au feu or wine" (Sanger 1983: 104). Roberts (1971) wrote of a working-class neighborhood in Manchester, England in the late nineteenth/early twentieth century: "Certain homely safeguards against conception had been known for generations, especially the small piece of oiled sponge with tapes hopefully attached adopted by women. Common, too, was the home-made pessary, a compound of lard (later margarine) and flour. This, thoughtfully carried in the handbag and judiciously used, saved many a girl's honour" (Roberts 1971: 34). In Salford, England information about these home-made devices was communicated verbally from one woman to another.

The importance of women's role in spreading information about methods of contraception through informal networks can also be seen in the case of Rendell's pessaries. When Rendell decided to manufacture his pessaries, he did not have the money to advertise them in pamphlets, books, or newspapers (Finch and Green 1963). Information was spread solely by word of mouth, but demand for his pessaries grew so rapidly that he was soon required to set up production on a large scale. Elderton's 1914 report also stressed the importance of informal networks in spreading information about birth control methods. "One correspondent reports an afternoon gathering of women, many of whom were 'good church-workers' and the subject under discussion was not the legitimacy of restriction, but the most effective means of restriction" (Elderton 1914: 34). Her report also noted that many women obtained information about birth control methods and ways of procuring abortion from midwives.

There is evidence that women in England actively sought information about birth control methods by attending lectures and buying books and pamphlets on the subject. After the Bradlaugh-Besant trial of 1877, huge crowds attended meetings to hear Besant and Bradlaugh speak about birth control, and several thousand copies of Knowlton's book were sold (Bland 1995). In the early 1880s, Bradlaugh and Besant held meetings in many towns in the north of England advocating birth control methods and distributing literature (Elderton 1914). Thousands of married women, including clergymen's wives, wrote to Annie Besant thanking her "for showing them how to escape from the veritable hell in which they lived" (Bland 1995: 196). Besant's book, The Law of Population, was written in response to this demand (Besant 1877). Some female members of the Malthusian League, such as Mrs. Thornton Smith, spoke about birth control at public meetings with working-class women, giving them advice on how to limit their families. Mrs. Thornton Smith told a public meeting at the South Place Institute in 1892 that "Many of these poor women came to her and asked her advice when they did not wish to have more children" (Bland 1995: 206). Elderton reports that lectures on the subject of birth control were held for "women only" in various towns in the north of England (Elderton 1914). 
Evidence as to the type of birth control used during the fertility transition in the late nineteenth and early twentieth centuries is scarce and, where available, is based on surveys of highly unrepresentative populations. The only survey we have found that was undertaken around that time is that of Clelia Mosher, who surveyed 47 American women about their sexual attitudes, including their use of contraception and the type of methods used (MaHood and Wenburg 1980). These women were members of the Mothers Club at the University of Wisconsin and were mostly college educated. Mosher found that a wide variety of methods were used to prevent conception-douches, pessaries, condoms, withdrawal, the safe period, and abstinence-with douching being the most common. Some women said that they had used different methods of birth control at different times. David and Sanderson argue that these couples combined the use of these methods with "a very considerable measure of sexual restraint within marriage" (David and Sanderson 1986: 313), leading to long interbirth intervals. There is no evidence of this in nineteenth-century Tasmania, where, with the exception of long final intervals due to "failed stopping," there was little increase in the length of other birth intervals (Moyle 2015). Elderton's survey quotes one working-class woman as saying "Self-restraint? ... Not much! If my husband started on self-restraint I should jolly well know there was another woman in the case" (Elderton 1914: 137).

As we noted earlier, advertisements for abortifacients were prevalent in the English newspapers in the late nineteenth and early twentieth centuries. It is not possible to tell whether abortions increased over this period, but Elderton argues that abortion was a common practice by the early twentieth century, and her report contains numerous references to various drugs used by working-class women in the north of England to procure abortions (Elderton 1914). A report in the British Medical Journal refers to the "pestilent traffic in so-called abortifacients" (BMJ 1899: 110). Several authors argue that the number of abortions among married women increased markedly across the Western world during the latter part of the nineteenth century (Accampo 2003; McLaren 1990). They agree that abortion was clearly a method of fertility control used by women to limit the size of their family, often without their husband's knowledge.

\section{Discussion}

All the evidence points to considerable agency on the part of women in the spread of control over fertility in the historical fertility transition in Australia. The 1903 Royal Commission concluded that women had played a crucial role in the nineteenth-century fertility decline in New South Wales. They viewed women's actions in adopting birth control practices as primarily responsible for the fall in the birth rate in that colony since the $1880 \mathrm{~s}$ 
(NSW 1904a: 17). Despite the Commissioners' vehement opposition to prevention and to the changes in women's behavior, attitudes, and lives, the Commission made very few recommendations to remedy "the various evils which are indicated by the evidence as the causes of the decline in the birth-rate" (NSW 1904a: 2). While they recommended changes to the sale of abortifacients and to the registration of lying-in homes to prevent them being used by abortionists, it appears that, in general, they felt powerless to stop the sale and/or use of preventives and to halt or reverse the changes that were occurring in women's lives. Several witnesses before the Commission considered that one of the main reasons women did not want many children was because of their love of "pleasure." Women of all classes wanted a life outside the domestic sphere and did not want to be burdened with a large family. Witness E thought that "The practice of preventing conception is followed because of the desire of women to have social pleasures" (NSW 1904b: 180), while Dr. Creed, a Sydney general practitioner, and Dr. Harris, a Newcastle general practitioner, both said that women did not want to be "bothered with children" (NSW 1904b: 124, 138). The Reverend Howell Price thought that the reason women wanted to limit the size of their family was that "the children tied them too much to the home and they did not wish to become slaves ...they want to be free, free from home ties and home duties as far as possible ...they desire to have more leisure, apparently for the pursuit of their own pleasure" (NSW 1904b: 214-5).

As a reflection of the decline of patriarchal systems, the Reverend Howell Price stated: "This desire to prevent the birth of children can undoubtedly be taken as a particular instance of a general relaxation of control over women, which has become the general sentiment during the last 30 or 40 years .... That relaxation of all control has led them into this particular desire to be free from restriction in that way too" (NSW 1904b: 216). This is not to claim that men played no part in fertility decision-making. Evidently, they did especially among the burgeoning middle class. Rather we argue that, counter to other studies, women played a prominent role in the selection of methods to control their own fertility.

Thus, in relation to Giddens's structuration theory, we conclude that in the latter part of the nineteenth century in Australia, social institutions departed both from the previously high levels of patriarchy that had applied in early years in Australia and from the patriarchy that apparently still remained prominent in Britain. Women's agency was reinforced by these institutional changes and, at the same time, furthered their progression in a duality between the macro and micro levels that is highly consistent with structuration theory. The centrality of the agency of women in the Australian fertility transition is overwhelming based on the contemporary micro-level evidence. Available evidence from other countries, while not as conclusive, is also supportive of the agency of women. 


\section{Notes}

1 Female suffrage applied in New Zealand from 1894 but it did not become a sovereign nation independent of Britain until 1907. Women's suffrage already existed in two of the Australian colonies, South Australia and Western Australia, prior to the Federation of Australia.

2 Only about 20 copies of the second volume were printed. Hicks (1978) located just two copies of the second volume still in existence. Copies are now available on microfilm in several libraries including the National Library of Australia and the Australian National University Library.

3 An outdoor clinic was an outpatient clinic at a public hospital for poor and working-class women.

4 While it is apparent that this woman did not take the advice that she was given by friends, her case indicates that women who had many children were subjected to advice about how to stop.

\section{References}

Abbasi-Shavazi, Mohammad Jalal, Peter McDonald, and Meimanat Hosseini-Chavoshi. 2009. The Fertility Transition in Iran: Revolution and Reproduction. Dordrecht: Springer.

Accampo, Elinor A. 2003. "The gendered nature of contraception in France: Neo-Malthusianism, 1900-1920," The Journal of Interdisciplinary History 34(2): 235-262, citing Anne-Marie Sohn 1996, Chrysalides: Femmes dans la vie privee (XIXe-XXe siecles). Paris: Publications de la Sorbonne, I, 511.

Allbutt, Henry A. 1888. The Wife's Handbook; How a Woman should order herself during Pregnancy, in the Lying-in Room, and after Delivery, with hints on the Management of the Baby. London: Forder. https://archive.org/details/39002086320026.med.yale.edu.

Allen, Judith A. 1990. Sex and Secrets: Crimes Involving Australian Women since 1880. Melbourne: Oxford University Press.

Alter, George. 1992. "Theories of fertility decline: A non-specialist's guide to the current debate," in John R. Gillis, Louise A. Tilly, and David Levine (eds.), The European Experience of Declining Fertility, 1850-1970: The Quiet Revolution. Cambridge, MA: Blackwell, pp. 13-27.

Anderson, Margaret and Alison MacKinnon. 2015. “Women's agency in Australia's first fertility transition: A debate revisited," The History of the Family 20(1): 9-23.

Banks, Joseph A. 1954. Prosperity and Parenthood: A Study of Family Planning among the Victorian Middle Classes. London: Routledge and Kegan Paul.

Becker, Gary S. 1981. A Treatise on the Family. Cambridge, MA: Harvard University Press.

Besant, Annie. 1877. The Law of Population: Its Consequences and Its Bearing upon Human Conduct and Morals. London: Freethought Publishing Company.

Bland, Lucy. 1995. Banishing the Beast: English Feminism and Sexual Morality, 1885-1914. London: Penguin.

Bongiorno, Frank. 2012. The Sex Lives of Australians: A History. Melbourne: Black Inc.

Boyce, James. 2010. Van Diemen's Land. Melbourne: Black Inc.

Branca, Patricia. 1975. Silent Sisterhood: Middle Class Women in the Victorian Home. London: Croom Helm.

Breward, Ian. 1988. Australia: The Most Godless Place under Heaven? Melbourne: Beacon Hill Press.

Briggs, Asa. 1968. Victorian Cities. Harmondsworth, England: Penguin Books.

British Medical Journal (BMJ). 1899. The Traffic in Abortifacients. January 14.

Brodie, Janet Farrell. 1994 Contraception and Abortion in Nineteenth-Century America. Ithaca: Cornell University Press.

Burnley, Ian. 1980. The Australian Urban System: Growth, Change and Differentiation. Melbourne: Longman Cheshire. 
Caldwell, John C. 1976. "Toward a restatement of demographic transition theory," Population and Development Review 2(3/4): 321-366.

- 1999. "The delayed Western fertility decline: An examination of English-speaking countries," Population and Development Review 25(3): 479-513.

Carlile, Robert. 1828 Every Woman's Book or What is Love? Containing Most Important Instructions for the Prudent Regulation for the Principle of Love and the Regulation of a Family. London: Carlile R. http://digital.library.lse.ac.uk.

Casterline, John B. 2001. "The pace of fertility transition: National patterns in the second half of the twentieth century," Population and Development Review 27(Suppl.): 17-52.

Coale, Ansley J. 1973. "The demographic transition reconsidered," in Proceedings of the International Population Conference, Liège. Vol. 1: 53-72. Liège: International Union for the Scientific Study of Population.

Coghlan, Timothy. 1887. The Wealth and Progress of NSW 1886. Sydney: George Robertson and Co.

Commonwealth of Australia. 1921. Census of the Commonwealth of Australia. Taken for the Night Between the $3^{\text {rd }}$ and 4th April, 1921, Part XXVIII: Families. Melbourne: H. J. Green.

Cook, Hera. 2000. "Unseemly and unwomanly behaviour: Comparing women's control of their fertility in Australia and England from 1890 to 1970," Journal of Population Research 17(2): $125-141$.

David, Paul and Warren Sanderson 1986. "Rudimentary contraceptive methods and the American transition to marital fertility control, 1855-1915," in Stanley L. Engerman and Robert E. Gallman (eds.), Long Term Factors in American Economic Growth. University of Chicago Press, pp. 307-390.

Davison, Graham. 1978. The Rise and Fall of Marvellous Melbourne. Melbourne University Press.

Dickinson, Robert L. and Lura Beam. 1931. A Thousand Marriages; A Medical Study of Sex Adjustment. Baltimore: The Williams and Wilkins Company. http://babel.hathitrust.org/cgi/pt?id= ucl.b3725419; view=lup;seq=3.

Drysdale, George R. 1861. The Elements of Social Science: or Physical, Sexual or Natural Religion. London: Truelove. Third Edition. First published 1854. https://books.google.com.au/books/about/ The_Elements_of_Social_Science.html?id=KG17KVlezZMC.

Easterlin, Richard A. 1975. "An economic framework for fertility analysis," Studies in Family Planning 6(3): 54-63.

Elderton, Ethel. 1914. Report on the English Birth Rate. London: Cambridge University Press.

Finch, Bernard E. and Hugh Green. 1963. Contraception through the Ages. London: Peter Owen.

Finlay, Henry. 1999. "Lawmaking in the shadow of the empire: Divorce in colonial Australia," Journal of Family History 24(1): 74-109.

Folbre, Nancy. 1983. "Of patriarchy born: The political economy of fertility decisions," Feminist Studies 9(2): 261-284.

Giddens, Anthony. 1984. The Constitution of Society: Outline of the Theory of Structuration. Berkeley: University of California Press.

Hacker, J. David and Rebecca Kippen. 2007. “A comparison of historical trends in marriage and fertility in the United States and Australia," paper presented at the Annual Meeting of the Social Science History Association, November.

Hicks, Neville. 1978. 'This Sin and Scandal': Australia's Population Debate 1891-1911. Canberra: Australian National University Press.

Kelly, Farley. 1982. "Mrs Smyth and the body politic," in Margaret Bevege, Margaret James, and Carmel Shute (eds.), Worth Her Salt: Women at Work in Australia. Sydney: Hale and Iremonger. - 1990. Smyth, Bridgetena (Brettena) (1840-1898 Australian Dictionary of Biography, National Centre of Biography, Australian National University, http://adb.anu.edu.au/biography/ smyth-bridgetena-brettena-8564/text14947, published first in hardcopy 1990. Accessed 6 December 2016.

Kent, Susan. 2014. Sex and Suffrage in Britain, 1860-1914. Princeton University Press.

Kippen, Rebecca. 2002. Death in Tasmania: Using Civil Death Registers to Measure Nineteenth-Century Cause-Specific Mortality. PhD thesis, Australian National University, Canberra. 
Knowlton, Charles. 1878. Fruits of Philosophy, or the Private Companion of Young Married People. Melbourne: Asher. nla.gov.au/digitalcollection. First published 1834.

Lesthaeghe, Ron and Chris Wilson. 1986. "Modes of production, secularization, and the pace of fertility decline in Western Europe, 1870-1930," in Ansley J. Coale and Susan Cotts Watkins (eds.), The Decline of Fertility in Europe. Princeton University Press, pp. 261-292.

MaHood, James and Kristine Wenburg (eds.) 1980. The 'Mosher' Survey': Sexual Attitudes of 45 Victorian Women/Clelia Duel Mosher. New York: Arno Press.

McCalman, Janet. 1988. Sex and Suffering: Women's Health and a Women's Hospital. Melbourne University Press.

McDonald, Peter. 1974. Marriage in Australia: Age at First Marriage and Proportions Marrying, 18601971. Australian Family Formation Project, Monograph No. 2, Department of Demography, Australian National University, Canberra.

. 2000. "Gender equity in theories of fertility transition," Population and Development Review 26(3): 427-439.

McDonald, Peter, Lado Ruzicka, and Patricia Pyne. 1987. "Marriage, fertility and mortality," in Wray Vamplew (ed.), Australian Historical Statistics. Sydney: Fairfax, Syme and Weldon.

McLaren, Angus. 1990. A History of Contraception: From Antiquity to the Present Day. Cambridge, MA: Basil Blackwell.

Magarey, S. 2001. Passions of the First Wave Feminists. Sydney: UNSW Press.

Moyle, Helen. 2015. The Fall of Fertility in Tasmania in the Late $19^{\text {th }}$ and Early $20^{\text {th }}$ Centuries. PhD thesis, Australian National University, Canberra.

New South Wales (NSW). 1904a. Royal Commission into the Decline in the Birth Rate and on the Mortality of Infants in New South Wales, Vol. I, Report and Statistics. Sydney: NSW Government Printer.

- 1904b. Royal Commission into the Decline in the Birth Rate and on the Mortality of Infants in New South Wales, Vol. 2, Minutes, Evidence, Exhibits, Index. Sydney: NSW Government Printer. Microfilm. Canberra: National Library of Australia.

Notestein, Frank W. 1945. "Population-the long view," in Theodore. W. Schultz (ed.), Food for the World. University of Chicago Press, pp. 36-57.

O'Lincoln, Tom. 2005. United We Stand: Class Struggle in Colonial Australia. Melbourne: Red Rag.

Pringle, Rosemary. 1973. "Octavius Beale and the ideology of the birth-rate: The Royal Commissions of 1904 and 1905," Refractory Girl 3: 19-27.

Quiggin, Patricia. 1988. No Rising Generation: Women and Fertility in Late Nineteenth Century Australia. Australian Family Formation Project, Monograph No. 10. Canberra: Department of Demography, Australian National University.

Radi, Heather. 1986. "Lawson, Louisa (1848-1920)," in Australian Dictionary of Biography, National Centre of Biography, Australian National University, http://adb.anu.edu.au/ biography/lawson-louisa-7121/text12285. Accessed 28 February 2016.

Reynolds, Henry. 2012. A History of Tasmania. Melbourne: Cambridge University Press.

Roberts, Robert. 1971. The Classic Slum: Salford Life in the First Quarter of the Century. Manchester University Press.

Robson, Lloyd and Michael Roe. 1997. A Short History of Tasmania. Melbourne: Oxford University Press. New Edition.

Ruzicka, Lado T. and John C. Caldwell. 1977. The End of the Demographic Transition in Australia. Australian Family Formation Project, Monograph No. 5, Department of Demography, Australian National University, Canberra.

Sanger, Margaret. 1983. Margaret Sanger: An Autobiography. New York: Pergamon Press.

Searle, Betty. 1988. Silk $\theta$ Calico: Class, Gender and the Vote. Sydney: Hale and Iremonger.

Spaull, Andrew. 1984. "The origins and formation of teachers unions in nineteenth century Australia," Melbourne Studies in Education 26(1): 134-168.

Szreter, Simon. 1996. Fertility, Class and Gender in Britain 1860-1940. Cambridge: Cambridge University Press.

Szreter, Simon, Robert A. Nye, and Frans van Poppel. 2003. "Fertility and contraception during the demographic transition: Qualitative and quantitative approaches," The Journal of Interdisciplinary History 34(2): 141-154. 
van de Kaa, Dirk J. 1996. “Anchored narratives: The story and findings of half a century of research into the determinants of fertility," Population Studies 50(3): 389-432.

Victoria. 1881. Census of Victoria 1881. Australian Data Archive, Australian National University. http://hccda.ada.edu.au/pages/VIC-1881-census.

Victoria, Office of the Government Statist. 1893. General Report on the Census of Victoria, taken on the $5^{\text {th }}$ April, 1891. Parliamentary Paper (Victoria Parliament).

Ward, Russel. 1966. The Australian Legend. Melbourne: Oxford University Press. Second edition.

Wright, Clare. 2014. "Goldstein, Vida Jane," in The Encyclopedia of Women and Leadership in Twentieth Century Australia. http://www.womenaustralia.info/leaders/biogs/WLE0160b.htm. Accessed 26 September 2017. 


\section{University Library}

\section{- M M I E R R A A gateway to Melbourne's research publications}

Minerva Access is the Institutional Repository of The University of Melbourne

Author/s:

McDonald, P;Moyle, H

Title:

Women as Agents in Fertility Decision-making: Australia, 1870-1910

Date:

2018-06-01

Citation:

McDonald, P. \& Moyle, H. (2018). Women as Agents in Fertility Decision-making:

Australia, 1870-1910. Population and Development Review, 44 (2), pp.203-230. https:// doi.org/10.1111/padr.12140.

Persistent Link:

http://hdl.handle.net/11343/254335 